\title{
The Problem of Life
}




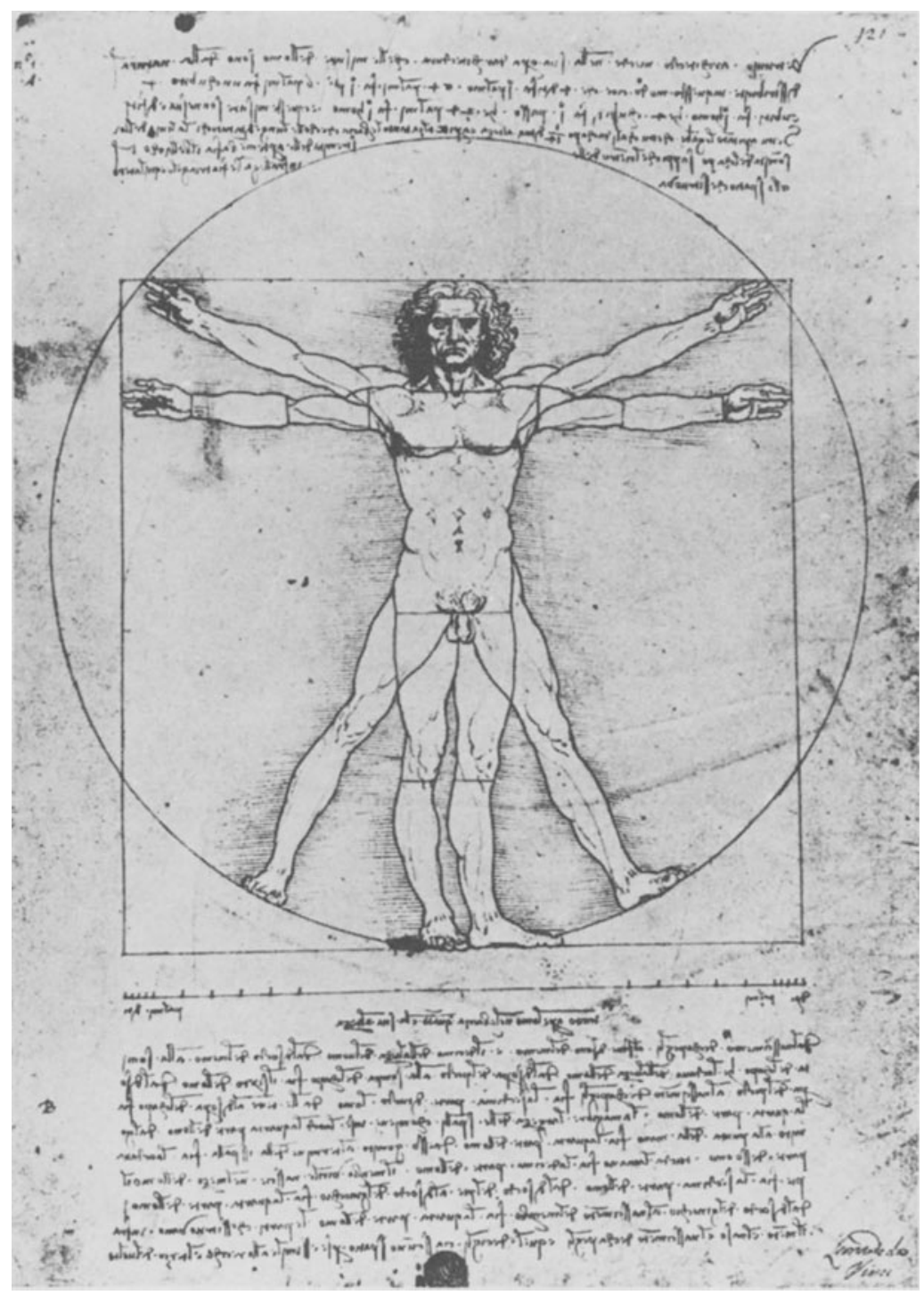

\section{'VITRUVIAN' MAN}

Leonardo da Vinci's famous drawing illustrates the theory of proportion worked out by the first-century Roman architect, Vitruvius. The theory proposed that a wellproportioned human body with feet together and arms outstretched fitted exactly into a square: a spread-eagled body, on the other hand, could be inscribed in a circle centred on the navel. Although Leonardo collected much data from living models, the reduction of human to geometrical proportion proved impossible. This Procrustean exercise has, however, been continued in a more abstract manner, and with greater success, by Leonardo's modern successors: the molecular biologists and biophysicists. 


\section{THE PROBLEM OF LIFE}

An Essay in the Origins of Biological Thought

\section{C.U.M.SMITH}

Department of Biological Sciences, University of Aston in Birmingham

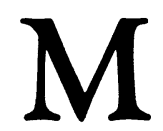


ISBN 978-1-349-02463-6 ISBN 978-1-349-02461-2 (eBook)

DOI 10.1007/978-1-349-02461-2

(C) C.U.M. Smith 1976

Softcover reprint of the hardcover 1st edition 1976 978-0-333-17781-5

All rights reserved. No part of this publication may be reproduced or transmitted, in any form or by any means, without permission

This book is sold subject to the standard conditions of the Net Book Agreement

First published 1976 by THE MACMILLAN PRESS LTD

London and Basingstoke

Associated companies in New York Dublin

Melbourne Johannesburg and Madras

SBN 333177819 
Then, what is life? I cried.

Shelley: The Triumph of Life

As to the past, history continues to be the means by which we recognise what is new as well as what is not.

Frank Kermode: Modern Essays

... there is assuredly no more effective method of clearing up one's own mind on any subject than by talking it over, so to speak, with men of real power and grasp, who have considered it from a totally different point of view. The parallax of time helps us to the true position of a conception as the parallax of space helps us to that of a star.

T.H. Huxley: On Animal Automatism 


\section{PREFACE}

This essay is of so prefatory a nature that it has no real need of any other preface. Writing this, as I am, surrounded by recently corrected galleys I am only too well aware of how many issues and how many periods have received all too cursory an examination. Yet to have attempted more would have risked obscuring the major themes in a fog of qualification and detail. I shall have succeeded if I have started sufficient intellectual hares to send the reader via the bibliography to the sources.

In the main I have concentrated on what appear to me to be salient episodes and seminal thinkers. These undoubtedly reflect my own biases and concerns. I must apologise in advance to readers interested in botany and microbiology. They will, I am afraid, find little about the origins of their subjects in the following pages. But it seems to me, as it seemed to Theophrastus the earliest of the historians of science, that the subject must have this partial (if not partisan) nature.

It remains to acknowledge, as in my previous books, my sense of indebtedness to the many men and women whose work and insight have illuminated the issues on which I have written. It remains also to acknowledge a sense of homage to the thinkers discussed in the following pages whom Claude Bernard likened to 'torches shining at long intervals to guide the advance of science. They light up their time . . .'

I am most grateful to the following sources for permission to reproduce illustrative material: Frontispiece, Venice Academy; Fig. 3.1 courtesy of Jonathan Cape from The History of Man by Carleton S. Coon (1955); Fig. 12.1 courtesy of the trustees of the British Museum; Fig. 13.2(a) courtesy of Anderson Giraudon; Fig. 13.2(b) courtesy of Staatsbibliothek Munchen Clm 23638 , fol. $11^{\mathrm{v}}$; Fig. 13.3 reproduced by gracious permission of Her Majesty Queen Elizabeth II; Fig. 14.2 courtesy of A. W. Singer Esq; Fig. 14.3 reproduced by gracious permission of Her Majesty Queen Elizabeth II; Fig. 16.3 courtesy of The Royal Society; Fig. 21.2 courtesy of J. C. Kendrew, F.R.S.; Fig. 21.3 courtesy of Mondadori Ltd. from Biologia Molecolare by C. U. M. Smith (1971); Fig. 22.1(a) courtesy A. W. Singer Esq.; Fig. 22.1(b) originally published by the University of California Press, reprinted by permission of the Regents of the University of California; Fig. 22.2 courtesy of the Hafner Press from The Historical Development of Physiological 


\section{Preface}

Thought edited by Chandler McC. Brooks and P. C. Cranefield (1959); Fig. 22.3 originally published by the University of California Press, reprinted by permission of The Regents of the University of California.

I am most grateful to the following sources for permission to reproduce extracts: Regents of the University of California Press; Penguin Books Ltd.; Johns Hopkins Press; the literary trustees of Walter de la Mare and the Society of Authors as their representative.

Finally I would like once again to thank my wife for help in typing and proof reading and for being the most loyal of critics.

C.U.M.S. 


\section{CONTENTS}

Preface

Introduction

1 The act of imagination

The semantic imperative

The esemplastic power

Culture-dependent seeing

The Copernican 'saving of the appearances'

Biologies

2 Beginnings

The 'interior and the 'exterior' view

Sympathetic magic

A living world

3 The palaeontology of some key words

The origins of language

Words and organisms

Some key words

4 Miletus

Introduction

Hybrid vigour

The technological origins of science

The quest for the 'primary substance'

The four elements

Microcosm and macrocosm

Break-up of the Ionian colonies 
5 The Italian shore

$\begin{array}{ll}\text { The western diaspora } & 35\end{array}$

Pythagoras $\quad 35$

Alcmaeon $\quad 37$

The Empedoclean physiology $\quad 39$

6 Elea and after

Being and not-being $\quad 45$

The paradoxes of Parmenides $\quad 45$

$\begin{array}{ll}\text { Retreat to atomism } & 47\end{array}$

A pandaemonium of particles $\quad 48$

Spiritual atoms $\quad 51$

Epicureanism $\quad 52$

7 The Timaeus

The just and the unjust $\quad 55$

Knowledge and opinion $\quad 56$

The doctrine of anamnesis $\quad 57$

An aristocrat's interpretation $\quad 59$

Timaeus' likely tale $\quad 60$

8 Aristotle: metaphysics

$\begin{array}{ll}\text { Biography of a philosopher } & 67\end{array}$

$\begin{array}{ll}\text { The analysis of sensation } & 68\end{array}$

$\begin{array}{ll}\text { The classification of knowledge } & 69\end{array}$

$\begin{array}{ll}\text { A predilection for biology } & 70\end{array}$

'Nature does nothing in vain' $\quad 71$

What is 'substance'?

$\begin{array}{ll}\text { Substance as 'creative act' } & 76\end{array}$

9 Aristotle: physical sciences

$\begin{array}{ll}\text { The physical treatises } & 77\end{array}$

The subject matter of physics $\quad 78$

$\begin{array}{ll}\text { Potential into actual } & 79\end{array}$

$\begin{array}{ll}\text { The embryological paradigm } & 80\end{array}$

The embryological analysis of the concept of cause $\quad 82$

$\begin{array}{ll}\text { A voidless cosmos } & 83\end{array}$

$\begin{array}{ll}\text { The projectile } & 86\end{array}$ 
10 Aristotle: life sciences

$\begin{array}{lr}\text { Biological research at the Lyceum } & 88\end{array}$

$\begin{array}{lr}\text { The concept of nature } & 89\end{array}$

Aristotle on the soul $\quad 92$

Subdivisions of the soul $\quad 94$

The cause of movement $\quad 95$

$\begin{array}{ll}\text { Physiological psychology } & 97\end{array}$

The insignificance of the brain $\quad 99$

$\begin{array}{ll}\text { Out-topping knowledge } & 100\end{array}$

11 Athenian afterglow

$\begin{array}{lr}\text { The Lyceum after Aristotle } & 102\end{array}$

$\begin{array}{ll}\text { Alexandria } & 103\end{array}$

Herophilus and the origins of human anatomy 103

The Erasistratean physiology 104

Galen of Pergamon $\quad 107$

$\begin{array}{ll}\text { Galenism } & 114\end{array}$

$\begin{array}{ll}\text { The Stoic physiology } & 114\end{array}$

12 Alchemy

Aristotle's Physics applied $\quad 119$

The artisan's Aristotle $\quad 120$

$\begin{array}{ll}\text { The psychobiology of matter } & 122\end{array}$

13 Mutation of the paradigm

$\begin{array}{ll}\text { The nature of Kuhnian paradigms } & 126\end{array}$

$\begin{array}{lr}\text { The evolution of machinery } & 127\end{array}$

Scholastic disputation $\quad 132$

$\begin{array}{ll}\text { The projectile again } & 136\end{array}$

$\begin{array}{ll}\text { The mechanistic paradigm } & 138\end{array}$

14 Escape from the labyrinth

Plato and Plotinus $\quad 140$

The correlation of accidents $\quad 142$

Atomism revived $\quad 144$

Art and anatomy $\quad 145$

William Harvey and the circulation theory 153

Harvey's Aristotelianism $\quad 155$ 
15 Descartes

Discretion the better part of valour $\quad 159$

Cogito ergo sum

Res cogitans and res extensa

160

Mind and brain

161

Cardiovascular physiology

162

Myoneural physiology

166

Determinants of the personality $\quad 169$

$\begin{array}{ll}\text { The pineal gland } & 170\end{array}$

The physical basis of memory $\quad 172$

The springs of human action $\quad 172$

$\begin{array}{ll}\text { Descartes' programme for physiology } & 174\end{array}$

16 Enlightenment

The consequences of Descartes $\quad 177$

William Croone's iatrophysics $\quad 177$

Borelli's De Motu $\quad 180$

Iatromechanics reaches an impasse $\quad 183$

$\begin{array}{lr}\text { Pneumatic chemistry } & 184\end{array}$

Energetics 186

$\begin{array}{lr}\text { The corpuscular hypothesis } & 189\end{array}$

17 The mechanisation of physiology

A false principle? 196

Search for the source of the body's warmth 197

Liebig originates biochemistry 199

The origins of neurophysiology 201

The units of life 208

The situation in mid-century $\quad 214$

Claude Bernard and le milieu intérieur $\quad 215$

18 The Romantic reaction

Is man a machine? $\quad 218$

The Critical Philosophy 221

A poet's biology 226

Naturphilosophie $\quad 229$

Embryology and the recapitulation theory 234

19 The origin of species

The selection of natural selection 
Systematics and the fixity of species $\quad 236$

$\begin{array}{ll}\text { Contrivances without a contriver } & 237\end{array}$

The principle of plenitude $\quad 239$

Bouleversement of the Aristocratic principle $\quad 240$

$\begin{array}{ll}\text { The days of creation } & 242\end{array}$

Catastrophism and Uniformitarianism 243

Lamarck and Erasmus Darwin $\quad 247$

The origin of the Origin $\quad 251$

20 The mechanism of heredity

Pangenesis: a provisional hypothesis $\quad 254$

The theoretical significance of pangenesis $\quad 255$

$\begin{array}{ll}\text { The germ plasm } & 256\end{array}$

Mendel's analysis $\quad 258$

Darwinian objectivity $\quad 259$

21 A clockwork embryo?

The absurdity of generatio aequivoca 262

William Harvey's theory of epigenesis $\quad 263$

$\begin{array}{ll}\text { The preformation theory } & 264\end{array}$

$\begin{array}{ll}\text { Nineteenth-century controversies } & 269\end{array}$

$\begin{array}{ll}\text { The Drieschean entelechia } & 272\end{array}$

The psychological paradigm and its challengers $\quad 273$

The evolution of matter-theory $\quad 275$

$\begin{array}{ll}\text { Self-assembly } & 276\end{array}$

22 Deactivation of the mind

A possible symmetry in the history of ideas? 281

$\begin{array}{ll}\text { Ventricular psychology } & 281\end{array}$

$\begin{array}{ll}\text { The problem of perception } & 285\end{array}$

Towards an experimental physics of the mind 286

$\begin{array}{ll}\text { Phrenology } & 291\end{array}$

The concept of a reflex 'arc' 294

The establishment of the neuron doctrine 296

$\begin{array}{ll}\text { Physiology of the brain } & 297\end{array}$

Hughlings-Jackson, David Ferrier and cerebral localisation 301

The comparison of brains to the artefacts of contemporary technology 304

The 'mental' and the 'physical' 305

$\begin{array}{ll}\text { An ineradicable duality } & 309\end{array}$ 
Appendixes

311

Bibliography

315

Index

331

xiii 


\section{ILLUSTRATIONS}

Frontispiece: Vitruvian man

1.1 An ambiguous figure: wife or mother-in-law?

1.2 An ambiguous figure: goose or rabbit?

3.1 Mesolithic hunters: Spanish cave art

4.1 Geography of the early Greek philosophers

5.1 Chronology of the early Greek philosophers

5.2 Clepshydra

11.1 The Erasistratean physiology

11.2 The rete mirable and the circle of Willis

11.3 Galen's cardiovascular physiology

12.1 Alchemy

13.1 Treadmill cranes

13.2 A large cannon being raised on to a guncarriage

14.1 Frontispiece of Tartaglia's Nova Scientia

14.2 The five figure diagram

14.3 Dissection of the principal organs of a woman

14.4 Pre-Vesalian dissection scene

14.5 The anatomy theatre at Padua

15.1 The Cartesian cardiovascular system

15.2 Reflex action according to Descartes

15.3 Pineal imagery according to Descartes

15.4 Automatic response to a visual image

16.1 William Croone's analogy between bladders and muscles

16.2 Giovanni Borelli's rhombal hypothesis (1)

16.3 Giovanni Borelli's rhombal hypothesis (2)

16.4 Plate IX from Borelli's De Motu Animalium

16.5 John Dalton's chemical symbolism (1)

16.6 John Dalton's chemical symbolism (2)

17.1 Galvani's electrophysiology

17.2 Robert Hooke's cork cells

18.1 A sixteenth-century mechanical hand

18.2 Archetype of the vertebrate skeleton

21.1 Spermatic homunculus

21.2 Model of the myoglobin molecule 
21.3 The T4 bacteriophage

22.1 Ventricular psychology

22.2 Leonardo's understanding of the cerebral ventricles

22.3 Map of the phrenological organs of the brain

22.4 David Ferrier's map of the brain

\section{TABLES}

13.1 Development of technology in Europe during the dark and middle ages

14.1 The origins of anatomy in western Europe 


\section{INTRODUCTION}

'What is life?' We have all asked ourselves Shelley's question-and probably had to be content with fairly dusty answers. This book tries to set the question in the perspective of history.

The story of the quest for an answer is largely the story of the growth of a science of biology. Largely, but not entirely; for the question 'What is life?' has concerned a circle far wider than that of the professional biologist. It has engaged the attention of poet and philosopher, theologian and physicist. This book, therefore, does not set out to be another academic study of the history of biology. It is not concerned so much to chronicle the minutiae of scientific advance as to investigate the historical and philosophical roots of our present understanding. Although I hope it will be of value to students of biology, I also hope it will be of interest to non-biologists.

Nowadays if we ask a professional biologist to say what 'life' is he would probably reply by describing the nature of self-replicating molecules, of energy-rich phosphate bonds and the mechanism of Darwinian evolution. If pressed he might agree that it was the name given to a peculiar state of matter existing at the interface between the planet and interplanetary space.

'This is a very recent vision of the nature of 'life'. It has hardly yet impinged upon the general consciousness. Only a few generations back it would have seemed merely wild speculation, and in the remoter past simply blasphemous.

'Life' must surely be something more than this? Is there no meaning, no purpose, no 'privileged axis'? How can the scientist who is, after all, a sentient being like the rest of us seem to deny the possibility of consciousness? For it seems clear that 'matter in motion cannot think'. The biologist seems to give us Hamlet without the Prince of Denmark.

It is a major part of the impulse of this book to show how it is that we are arrived at this position. For it is too easily forgotten that the glittering spectacle of modern science and, in particular, of modern life science is but the surface of a historical process stretching back two millennia and more. In any account of contemporary science, whether it be of molecular biology or of neusobiology, we are bound to skim over the surface of countless unstated assumptions. To begin to answer Shelley's question we have, I believe, to investigate the hidden depth of our science. We have to use the perspectives 


\section{Introduction}

of history to provide the parallax necessary to see ourselves and our science in the round.

It is clear that there are numerous ways of composing a book having the objectives outlined above. One might have taken isolated historical epochs, perhaps the Aristotelian biology of the fourth century BC, the Cartesian biology of the late seventeenth century and the biology of the nineteenthcentury Naturphilosophie, and used them as triangulation points to determine the position and status of our present concepts. Or, perhaps, one might have analysed in depth the development of certain key biological concepts, epoch by epoch. Or one might have attempted to show how throughout the two millennia of our history social and economic forces have influenced biological theory and hence, by implication, suggest that we too are not immune from this bias. The approach finally adopted partakes to some extent of all three of those mentioned above. It tries, however, to set them in the frame of a continuous narrative and an unfolding plot. For, as I have already mentioned, I have tried to write a book which can appeal not only to students of biology but also to the general reader. For we are all interested in the answer, or the answers, to Shelley's question.

One way of viewing the historical process related in the ensuing pages is to see it as a progressive unravelling of a primitively inextricably intertwined knot of ideas. The most prominent threads in this tangled knot might be labelled the notions of 'objectivity' and 'subjectivity'. One of the book's major themes thus consists in following the gradual unravelling of these two attitudes towards events from their early entanglement. Another way of describing the same process is to say that one of the most important themes in the evolution of science in general and of biology in particular has been the separation of a teleological (animistic) from a non-teleological (mechanistic) account of the world.

Our subjective experience seems indisputably to be that of a 'tissue of purposes'. Few would quarrel with the existentialist's insistence that 'intentionality is consciousness'. Explanations of our own behaviour are invariably couched in terms of 'final' causes. We act to realise certain aims and ambitions. The scientific account of the world 'outside', however, disdains all recourse to teleological explanation. Final causes are anathema to the scientist. Such explanations seem to him to stifle further investigation. Scientific 'explanations' are invariably couched in terms of 'efficient' causes. The billiard ball does not progress across the table because it seeks the pocket but because it has received an impulse of appropriate strength and direction from the billiard cue. The heart does not beat with increased rapidity because it perceives a sudden danger and hence the need to escape but because of the influence of certain chemicals on its 'pacemaker' region. At the beginning of our history, however, we shall find these two types of 


\section{Introduction}

explanation, the teleological and the non-teleological, systematically conflated.

The unravelling of objectivity and subjectivity, of final and efficient causation, has by no means been a continuous process. For long periods of time little advance was made. It seems, indeed, that 'progress' could only occur when the underlying social and technological conditions were appropriate. These conditions, to use an analogy due to Scheler (1), act as a valve controlling the development of scientific ideas. When social conditions are inappropriate the valve closes and prevents further scientific advance; when social conditions change the valve opens.

Now one of the crucial notions of an 'objective' or 'mechanistic' theory of nature is the notion of 'blindly running atoms'. If the phenomena of the world can be shown to be the outcome of the interaction of such submicroscopic 'billiard balls' then the case for teleology is very severely weakened. We shall see in the early chapters of this book that the intellectual origins of the atomic theory are to be found amongst the Eleatics and their Abderan successors in the fifth century BC. The theory, in fact, is the logical outcome of the early Greek way of looking at the world. But as we have just seen it has certain extrascientific implications. It implies that all the scents and sounds and colours of the world, all the strategems, ambitions and achievements, are but the outcome of 'chance and necessity' (2). The world emerges from the mere random collocation and dislocation of purposeless atoms. The theory implies that teleological explanations in terms of intention, whether human or divine, are illusory. These atheistic concomitants were unacceptable to societies which depended upon religious belief for their social cohesion. The atomic theory thus provides a classic instance of Scheler's 'social valving'. After a brief florescence in the ancient world it was outlawed until the seventeenth century AD.

Now the history of the atomic theory is closely bound up with the history of biological thought, for, as we have just noticed, it was from its inception profoundly non-teleological. It thus provided from the first a very considerable stumbling block for the biologist. We shall see, for example, the scornful reaction it produced in Aristotle, Galen and Harvey-three of biology's greatest names. Aristotle, the greatest of the three, was especially opposed. For not only was his biological intuition thoroughly outraged-how was an atomic theory of embryology possible?-but the teleological metaphysics which he had discussed at Plato's Academy for nearly twenty years was also totally antipathetic. This metaphysics had, of course, a social origin. It will be briefly discussed in chapter 7 .

(1) M.Scheler, Die Wissensformen und die Gesellschaft, 1925. A useful account of Scheler's ideas is to be found in P.L.Berger and T.Luckmann, The Social Construction of Reality, Penguin, Harmondsworth (1967).

(2) A phrase from Democritus which Jacques Monod has used as the title for a celebrated book. 


\section{Introduction}

The evolution of the modern science of life is thus closely tied up with the evolution of the atomic theory of matter. Only when this had been achieved did it become possible to apply Occam's razor to the vital principles and entelechies which had formerly been conceived to occupy the bodies of living organisms. Contemporary molecular biology, perhaps the most significant of all advances towards an answer to the Shelleyan question, would have been impossible without the modern understanding of the nature of atoms and the complexes atoms form. Thus any consideration of the evolution of biological thought must include some account of the evolution of the atomic theory of matter.

It is interesting to notice (as Scheler would have predicted) that the post-seventeenth-century mechanistic biology, like its Aristotelian predecessor, had its sociological roots. For the atomic principle, in its widest sense, also lies at the source of Hobbes's bourgeois social philosophy. Society, the 'Leviathan', is seen as emerging from the interaction of innumerable 'blindly running' 'nasty, brutish and short' lives. The analogy is clear. Just as the expansions of gases are to be explained in terms of their invisible atomic constituents, so the behaviour of the state emerges from a summation of the multitudinous doings of its citizenry.

It is interesting, furthermore, to observe that the Hobbesian analysis also lies at the root of the empiricist doctrine of mind (chapter 22) and, through Godwin and Malthus, of the Darwinian theory of evolution (chapter 19). It was only when all these consequences had been fully worked through that it became clear that no natural event need escape the mechanistic interpretation. It is a great part of this book's object to trace the course of this dawning understanding in the realm of biology. For it is only in quite recent times that the full sharpness of the dichotomy between the 'subjective' and the 'objective' has become inescapable.

Our suggestion, then, is that the triumph of the atomic principle, of mechanism, in the modern world is connected at a deep level with the underlying evolution of society. It is the reflection of, or, better, it is allowed by, the triumph of a more manipulative, more operational, outlook. If one takes the next step and asks what it was that led to this triumph, then the obvious answer is the evolution of technology itself. Even in the ages of faith a slow but steady development of the means of production occurred in Europe (see chapter 13). And, going right back to the beginning of our history, we shall see, in chapter 3 , that anthropologists are inclined to believe that it was man's early stone technologies which forced the development of his intelligence and his linguistic powers. It is part of the argument of the present book that technology has continued this role down to the present day. Only those things which man has created himself, which he has thoroughly learned to manipulate and control, does he fully comprehend.

The operational understanding gained from a familiarity with technology (in the widest sense of that term) can be used to gain an insight into the way 


\section{Introduction}

naturally occurring entities, for example organisms, function. The lines of influence, of action and reaction, are thus complex and intertwined. The development of technology provides new explanatory paradigms. These, in turn, provide new ways of understanding and organising society. The spiral takes another turn when the perceived form of our society partly conditions the type of explanatory paradigm we prefer. The advance of scientific theory is thus partly controlled by social forces, partly by the practical techniques which society has mastered and last, but not least, partly by the sheer logic of ideas. The scientific 'objectivity' of which we are nowadays so proud is thus the expressiun of a whole complex of underlying socioeconomic and technological forces. Is it perhaps nothing more than the reflection of this 'reality' in our ineradicable subjectivity?

This 'complex of forces' lies behind the history outlined in this book. The 'open' societies of the Presocratics were succeeded by 'closed' societies whose theory was propounded at Athens and which spread in fact over all Europe in the centuries following the fall of Rome. The teleological biologies of Aristotle, Galen and Harvey reflect this social reality. The more 'open' societies which have succeeded the rebirth of science have, in turn, allowed the development of a mechanistic biology. The harbinger of this non-teleological biology was René Descartes. Descartes' mechanistic vision could, however, only be accepted in its full depth after the triumph of the Darwinian evolution theory in the early twentieth century. It is thus only in very recent times that we have become fully aware of the totally impersonal nature of the scientist's interpretation of the world. It is only in very recent times that the biologist is able to answer Shelley's question with conviction. 'What is life?' 'Read this text on biochemistry and then this on physical chemistry and this on physics'.

The book starts with a brief account of the part played by the human imagination in the formation of scientific theory. AlbertEinsteinconsidered scientific theories to be 'free creations of the human mind' and the first chapter seeks to emphasise this point of view. Such theories are the outcome of the mind's activity: its unceasing attempt to make sense of its surroundings. This drive seems to be basically the same in both the sciences and the arts. In both cases the data of experience are continually shuffled, consciously and/or unconsciously, until a meaningful pattern is obtained.

The next two chapters lay some of the essential groundwork for the subsequent discussion of biological theory in antiquity. In chapter 2 an attempt is made to show how alien to our present modes of thought were some of the predominant modes of thought in the primitive world. To understand the world-view of sympathetic magic requires an imaginative effort similar to those described in chapter 1 . Instead of 'seeing' the world as a gigantic 'mechanism' the primitive mind is more inclined to see it as a personality, its parts interconnected not by 'external' forces but by mysterious indwelling sympathies. Chapter 3 takes up much the same major 


\section{Introduction}

point showing that the words which we now apply at key points in our science-action, energy, movement, nature, cause, and so on-frequently had rather different connotations for the ancients. Their meanings seem, on the whole, to have been far richer: they contained psychical as well as physical reference. This is one more indication that in ancient times subjectivity and objectivity (the 'for-itself' and the 'in-itself', to use Sartre's terminology) were by no means as sharply distinguished as they have become today.

The history proper begins in chapter 4 with a discussion of early Greek science. It is hoped that the first three chapters have prepared the ground for this discussion of theories which may look absurd to twentieth-century eyes but which are in fact some of the most penetrating in existence. It is important to recognise that this early thought is almost equal parts poetry and science. It is partly for this reason that the discussion in chapter $1 \mathrm{dwelt}$ on the theory of the imagination developed by the English Romantic poets.

The discussion of Presocratic Greek thought continues through chapters 5 and 6 . In chapter 6 the important theme of atomism makes its first major appearance. As mentioned earlier in this introduction, the tension between this theory and the biologist's perpetual confrontation with 'fitness for purpose' is felt throughout our history.

Following chapter 6 come a group of chapters which consider the climax of classical biological thought first at Athens and finally in Alexandria and Rome. Here another of the book's themes makes its appearance: the effect of social conditions on scientific thought. Following Benjamin Farrington it is argued that Socrates' prime purpose was to save the Athenian democracy from the demagogues. The dialogues depend crucially on the doctrine that education consists in 'drawing out', in making explicit what is all the time implicit. Every slave has buried within him, unknown to him, the principles of geometry. Similarly every Athenian was possessed, in however hidden a fashion, of immutable forms of virtue, justice, statesmanship, and so on. If Athenians could only be brought to recognise the existence of these forms and that they had an incorrigibility similar to the truths of geometry, then all men could agree on what was best and on how the state should be governed.

But where were these hidden forms? Socrates believed that they were implanted before birth into the soul. The doctrine that the soul lies behind the body's appearances and governs its activities is taken up by Socrates' disciple : Plato. Plato makes great use of it throughout his work, and importantly for our purposes in the physiological psychology of the Timaeus. Plato's thought is thus thoroughly teleological: the ends govern the means. The contrast with the open Democritean vision is sharp and clear.

Plato's teleological metaphysics could scarcely have failed to influence his star pupil, Aristotle, who spent seventeen of his formative years at the Academy. Aristotle was moreover deeply involved in all aspects of biology. It need not therefore surprise us to find that not only the Stagirite's biology was 
deeply teleological but also his physics and his metaphysics. His perception that 'nature does nothing in vain' pervades his work. Aristotle, like the modern, saw no important dichotomy between the animate and the inanimate. There is, however, a vital distinction: whereas moderns seek to describe animate creation in terms derived from inanimate nature, Aristotle sought to do the opposite. His effort was so powerful, so well-articulated, so persuasive that his influence lasted two thousand years. Indeed it is still active today. It is for this reason that three chapters of the present book are devoted to his thought. He was, and is, as Darwin and many others have pointed out, the greatest of those who have attempted an answer to the question 'What is life'?

From Aristotle to Descartes there is a span of nearly two millennia. These nineteen hundred years of human endeavour are skimmed in four chapters. Such are the exigencies of one who would write a book in finite time and of finite size on the history of biological ideas. The first two of these four chapters discuss the aftermath of the great Athenians in the late classical and early mediaeval periods. We see how the habit of applying concepts derived from biological observation and psychological experience to inanimate nature impeded the growth of both physics and chemistry. In particular the great and long-enduring study of alchemy is seen as an instance of just this misapplication of ideas. In the last two of this set of four chapters the forces leading to an escape from this blind alley are considered. The slow evolution of technology is seen as the chief of these ultimately revolutionary forces. Once the Galilean insight had been accomplished, however, the way was clear for the development, or at least the promulgation, of a mechanistic biology.

René Descartes, in his justly famous division of being into the mental and the physical, permitted the development of a thoroughly mechanistic account of the physiology of the body. Descartes' psychophysiological speculations are considered in chapter 15. Speculations, however, they were bound to be, for in the seventeenth century the basic sciences of physics and chemistry just had not been developed far enough to allow an experimentally-based physicalist treatment of biology. The most important prerequisite was an understanding of the science of matter and of material change. Thus in chapter 16, after a preliminary look at the dead end into which post-Cartesian iatrochemists and iatrophysicists had worked themselves, the discussion turns to a brief review of the eighteenth-century chemical revolution.

Once this revolution had been accomplished the way was clear for the fulfilment of Descartes' vision. The mechanisation of physiology was largely the work of nineteenth-century workers, culminating in the syntheses of Claude Bernard and Charles Sherrington. 'What is life'? 'An intricate physicochemical mechanism'. 


\section{Introduction}

But late eighteenth and early nineteenth-century vitalists did not give in without a struggle. The differences between the crude automata of those days and the flexibility of living organisms was too glaring to be overlooked. Moreover a satisfactory answer to Shelley's question demanded some answer to the origin question. Engineering automata are, after all, built by engineers. Were living beings created by an Engineer in the skies? And if so did He perhaps imbue them with some special non-physical principle?

The origin problem was, of course, solved in essence by mid-nineteenthcentury evolutionary theory. The emergence of the Darwinian theory is recounted in chapter 19. Darwinism, however, remained 'soft-centred' until a satisfactory understanding of the mechanism of heredity had been built up. This understanding required almost another century to accomplish. Thus it was not until the mid-point of the twentieth century had come and gone that the biologist could return a confident answer to Isaac Newton's query 'How came the bodies of animals to be contrived with so much art...'?

The last two chapters of the book carry the mechanistic analysis into the heartland of the teleological principle: firstly into embryology and then into neurobiology. Is it possible to show that physicalist interpretations obtain in these two fields also? It will be recalled that Aristotle had tried the exact opposite. He had attempted to use concepts suited to embryology and introspective psychology to describe physical phenomena. One may feel, however, that the mechanisation of embryology and neurobiology has been far more successful than the ancient attempt to vivify physics.

It has been more successful partly because of the evolution of matter theory during the nineteenth and twentieth centuries. The present understanding of how atoms combine and recombine to form structures of ever greater complexity is a far cry from the discordant heaps and whirlpools envisaged by the Democriteans. The atom, moreover, has been shown to have a structure, to be splittable: a contradiction in terms to the ancients. It is thus the subatomic particle which truly corresponds to the concept of the founders of the theory. But here, of course, a radical difference obtrudes. The subatomic 'particle' since de Broglie and Schroedinger is understood to be also a wave. Thus are the ancient paradoxes resolved. And it is in modern molecular biology that the two-thousand-year tension between atom and organism at last finds a solution. The advent of $\mathrm{X}$-ray diffraction and electron microscopy has shown there to be no discontinuity in fact, the evolving concept of the nature of the chemical bond has shown there to be no dissimilarity in concept, between the chemist's and the biologist's world.

But what of mind? Can this, too, be mechanised? The explosive development of computer science suggests an affirmative answer. A more careful analysis, however, suggests caution. In chapter 22 we trace the historical process whereby the 'mind', for long considered the 'active' principle of the organism and, indeed, the world, becomes transformed into a reflex mechanism: no longer a 'self-moved mover' but a contrivance reacting 


\section{Introduction}

to external forces in a passive and ultimately predictable way. This revolutionary insight became possible immediately Descartes divided mind from matter. By the same token it remains only half the story. For our personal, subjective, experience remains as it was for the ancients: purposeful, goal-seeking. The book thus ends by drawing attention once more to this deep dichotomy.in our understanding of things. The world we treat as if it were a mechanism drawing analogies from the technologies we have uurselves created; ourselves we understand teleologically. What is life? We still cannot answer. For our theories are man-generated, man-orientated; as Kant saw, they are in a way imposed upon the world. In one sense we can say that life, we ourselves, are at one with the Earth: are sprung from the planet's side and consequently fall within the province of natural science. In another and complementary sense we are embodiments of consciousness, of perception and understanding. We know what it is like to be the mechanism which the neurosurgeon dissects. 'What is life'? Both answers are valid. It is a physicochemical mechanism; it is the experience of intention and purposeful activity, of sadness and joy. 